\title{
Prevention of soya-induced enteritis in Atlantic salmon (Salmo salar) by bacteria grown on natural gas is dose dependent and related to epithelial MHC II reactivity and CD8 $\alpha^{+}$intraepithelial lymphocytes
}

\author{
Odd H. Romarheim ${ }^{1 *}$, Dyveke L. Hetland ${ }^{1}$, Anders Skrede ${ }^{1}$, Margareth $\varnothing_{\text {verland }}{ }^{1}$, Liv T. Mydland ${ }^{1}$ \\ and Thor Landsverk ${ }^{2}$ \\ ${ }^{1}$ Department of Animal and Aquacultural Sciences, Aquaculture Protein Centre, CoE, Norwegian University of Life Sciences, \\ PO Box 5003, NO-1432 As, Norway \\ ${ }^{2}$ Department of Basic Sciences and Aquatic Medicine, Norwegian School of Veterinary Science, Oslo, Norway
}

(Submitted 27 January 2012 - Final revision received 27 April 2012 - Accepted 23 May 2012 - First published online 20 July 2012)

\begin{abstract}
An experiment was carried out to study the preventive effect of bacterial meal (BM) produced from natural gas against plant-induced enteropathy in Atlantic salmon (Salmo salar). Salmon were fed a diet based on fish meal (FM) or seven diets with $200 \mathrm{~g} / \mathrm{kg}$ solvent-extracted soyabean meal (SBM) to induce enteritis in combination with increasing levels of BM from 0 to $300 \mathrm{~g} / \mathrm{kg}$. Salmon fed a SBM-containing diet without BM developed typical SBM-induced enteritis. The enteritis gradually disappeared with increasing inclusion of BM. By morphometry, no significant $(P>0.05)$ differences in the size of stretches stained for proliferating cell nuclear antigen were found with $150 \mathrm{~g} / \mathrm{kg}$ BM compared with the FM diet. Increasing BM inclusion caused a gradual decline in the number of cluster of differentiation $8 \alpha$ positive $\left(\mathrm{CD} 8 \alpha^{+}\right)$intraepithelial lymphocytes, and fish fed $\mathrm{BM}$ at $200 \mathrm{~g} / \mathrm{kg}$ or higher revealed no significant difference from the FM diet. Histological sections stained with antibody for MHC class II (MHC II) showed that fish with intestinal inflammation had more MHC II-reactive cells in the lamina propria and submucosa, but less in the epithelium and brush border, compared with fish without inflammation. There were no significant $(P>0.05)$ differences in growth among the diets, but the highest levels of BM slightly reduced protein digestibility and increased the weight of the distal intestine. In conclusion, the prevention of SBM-induced enteritis by BM is dose dependent and related to intestinal levels of MHC II- and CD8 $\alpha$-reactive cells.
\end{abstract}

Key words: Bacterial meal: Soyabean meal: Atlantic salmon: Enteritis

Conventional solvent-extracted soyabean meal (SBM) disturbs intestinal homeostasis in salmonids and initiates enteropathy in the distal part of the intestine, commonly referred to as SBM-induced enteritis ${ }^{(1)}$. The first signs of enteropathy are noticeable after a few days on diets containing SBM, thus restraining the use of SBM for salmonids. The severity of enteropathy is dependent on both the inclusion level of $\mathrm{SBM}^{(2)}$ and the origin of the soyabeans ${ }^{(3)}$. Inflammation is associated with enhanced intestinal permeability ${ }^{(4)}$, reduced endocytotic uptake of macromolecules ${ }^{(5)}$ and increased proliferation of intestinal epithelial cells attributed to alterations of epithelial cell differentiation and maturation ${ }^{(6,7)}$. Also, the activities of trypsin in the intestinal digesta and a trypsin-like protease in the intestinal mucosa increase $^{(8)}$, whereas the reactivities of several brush-border enzymes decrease $^{(7)}$.
Saponins interacting with other alcohol-soluble components are the most likely feed components that either directly or indirectly disrupt the intestinal barrier ${ }^{(9,10)}$. An increase in intestinal epithelium permeability might expose inflammationinducing receptors on the otherwise shielded basolateral surfaces of epithelial cells to luminal antigens, which in turn initiate a T-cell-mediated inflammation ${ }^{(11,12)}$. Augmented levels of cell populations reacting for MHC II antibodies and the recently established monoclonal antibodies to detect cluster of differentiation $8 \alpha(C D 8 \alpha)^{(13)}$ are therefore expected in response to SBM-induced enteritis.

Inclusion of microbial protein sources and extracts from microbes or yeast rich in nucleotides, phospholipids, cell wall oligo- and polysaccharides, and other bioactive components in fish diets might affect gut microflora, disease resistance and growth performance ${ }^{(14-16)}$. A recent study by

Abbreviations: BM, bacterial meal; BW, body weight; CD8 $\alpha^{+}$, cluster of differentiation 8 $\alpha$ positive; FM, fish meal; Foxp3, forkhead box p3; PCNA,

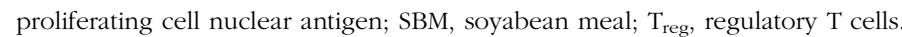


Romarheim et al. ${ }^{(6)}$ revealed that bacterial meal (BM) containing mainly Methylococcus capsulatus grown on natural gas prevents the development of SBM-induced enteritis in Atlantic salmon. BM has proved to be a suitable protein source for fish as well as other monogastric animals, and there are no restrictions on its use in diets for farmed animals within the European Union ${ }^{(17)}$. Dietary inclusion of $\mathrm{BM}$ has also been shown to increase the intestinal weight $(\mathrm{g} / \mathrm{kg}$ whole body) in salmonids ${ }^{(6,18)}$, which indicates a profound effect of $\mathrm{BM}$ on the intestinal wall.

The present experiment was designed to study intestinal changes associated with enteropathy in Atlantic salmon fed diets with a high content of SBM in combination with graded levels of BM. We hypothesised that (1) the protective effect of BM against SBM-induced enteritis is dose dependent, (2) the inflammatory response will be linked to the enhanced density of inflammation markers in salmon such as MHC II and CD8 $\alpha$ positive $\left(\mathrm{CD} 8 \alpha^{+}\right)$T lymphocytes and (3) dietary $\mathrm{BM}$ will normalise the expression of these inflammation markers.

\section{Materials and methods}

\section{Diets and fish experiment}

For the present experiment, eight diets were formulated: a fish meal (FM)-based control diet, and seven diets with the FM replaced by $200 \mathrm{~g} / \mathrm{kg}$ SBM combined with BM levels ranging from 0 to $300 \mathrm{~g} / \mathrm{kg}$ BM (Table 1 ). The diets were formulated to have similar ratios among crude protein, crude lipid and starch based on analyses of the feed ingredients. Feed was produced at the Center for Feed Technology at the Norwegian University of Life Sciences, Ås, Norway, using extrusion technology and vacuum coating with fish oil after drying. The finished feed pellets were $3.5 \mathrm{~mm}$ in diameter.

The fish experiment was carried out at the Nofima research station at Sunndalsøra, Norway. Non-vaccinated Atlantic salmon (Salmo salar) with an average initial weight of $273 \mathrm{~g}$ were randomly distributed into sixteen tanks (fifty fish/tank). The tanks contained 460-litre seawater each $\left(10 \cdot 3^{\circ} \mathrm{C} ; 32.5 \mathrm{~g} \mathrm{NaCl} / 1\right)$ and were supplied with 18 litres water/ min and light $24 \mathrm{~h} / \mathrm{d}$. All fish were fed the FM diet during the last 3 weeks before the feeding experiment to avoid interactions with the commercial diet used at the research station. Thereafter, each of the eight experimental diets were fed to two replicate fish tanks every $32 \mathrm{~min}$ by electrically driven disc feeders for $47 \mathrm{~d}$. Feed intake was measured according to the method of Helland et al. ${ }^{(19)}$. The experiment was conducted in accordance with the regulations given by the National Animal Research Authority in Norway (Animal Protection Ordinance concerning experiments with animals of 15 January 1996).

\section{Sampling and chemical analysis}

Fish were weighed at the start and end of the experiment. At the termination of the experiment, all fish were anaesthetised with tricaine methanesulfonate $(60 \mathrm{mg} / 1$ water $)$ and killed by a sharp blow to the head. Tissue from the distal intestine of six fish/tank was fixed in 10\% neutral phosphate-buffered formalin for $2 \mathrm{~d}$ before being dehydrated in ethanol, equilibrated in xylene and embedded in paraffin according to standardised routines. Faeces were stripped from the remaining fish in each tank according to the procedure described by Austreng ${ }^{(20)}$, pooled by tank, frozen and freeze-dried before the analysis. The gastrointestinal tract from ten fish/tank was emptied for digestive chyme and weighed. Thereafter, the gall bladder and fat from the mid- and distal intestine were removed, and the weight of the liver, stomach, pyloric region, mid-intestine and distal intestine was measured.

Diets and faeces were analysed for DM $\left(105^{\circ} \mathrm{C}\right.$ overnight), ash $\left(550^{\circ} \mathrm{C}\right.$ overnight), crude protein (Kjeldahl, $\left.\mathrm{N} \times 6.25\right)$, crude lipid after hydrolysis with petroleum diethyl ether on an accelerated solvent extractor (Dionex ASE200; Dionex), and starch as total glucose after hydrolysis with $\alpha$-amylase and amyloglucosidase after lipid removal by acetone. Yttrium as a marker for nutrient digestibility was determined by

Table 1. Formulation and analysed chemical composition of the experimental diets

\begin{tabular}{|c|c|c|c|c|c|c|c|c|}
\hline & FM diet & 0-BM diet & 25-BM diet & 50-BM diet & 100-BM diet & 150-BM diet & 200-BM diet & 300-BM diet \\
\hline \multicolumn{9}{|l|}{ Ingredients ( $\mathrm{g} / \mathrm{kg}$, as-fed basis) } \\
\hline FM & $642 \cdot 4$ & 459.4 & 436.4 & $412 \cdot 4$ & 364.4 & $316 \cdot 4$ & 269.4 & 174.4 \\
\hline $\mathrm{SBM}^{*}$ & - & $200 \cdot 0$ & $200 \cdot 0$ & $200 \cdot 0$ & $200 \cdot 0$ & $200 \cdot 0$ & $200 \cdot 0$ & $200 \cdot 0$ \\
\hline $\mathrm{BM} \dagger$ & - & - & $25 \cdot 0$ & $50 \cdot 0$ & $100 \cdot 0$ & $150 \cdot 0$ & $200 \cdot 0$ & $300 \cdot 0$ \\
\hline Fish oil & $189 \cdot 0$ & $184 \cdot 0$ & 183.0 & $182 \cdot 0$ & $181 \cdot 0$ & $180 \cdot 0$ & $178 \cdot 0$ & $175 \cdot 0$ \\
\hline Wheat & $163 \cdot 0$ & $151 \cdot 0$ & $150 \cdot 0$ & $150 \cdot 0$ & $149 \cdot 0$ & $148 \cdot 0$ & $147 \cdot 0$ & $145 \cdot 0$ \\
\hline Vitamin/mineral premix $\ddagger$ & $5 \cdot 6$ & $5 \cdot 6$ & $5 \cdot 6$ & $5 \cdot 6$ & $5 \cdot 6$ & $5 \cdot 6$ & $5 \cdot 6$ & $5 \cdot 6$ \\
\hline \multicolumn{9}{|l|}{ Analysed composition } \\
\hline DM & 940 & 943 & 943 & 948 & 939 & 934 & 934 & 932 \\
\hline Crude protein (g/kg DM) & 479 & 456 & 456 & 460 & 447 & 477 & 463 & 460 \\
\hline Crude lipid (g/kg DM) & 245 & 229 & 229 & 232 & 242 & 252 & 242 & 248 \\
\hline Starch $(\mathrm{g} / \mathrm{kg} \mathrm{DM})$ & 128 & 120 & 109 & 114 & 119 & 96 & 105 & 108 \\
\hline Total ash (g/kg DM) & 100 & 89 & 88 & 85 & 81 & 84 & 79 & 70 \\
\hline
\end{tabular}

FM, fish meal; BM, bacterial meal; SBM, soyabean meal.

* Deno-Soy F, solvent-extracted and toasted SBM (Denofa).

†BioProtein (Norferm AS).

‡ Supplied/kg of diet: all-trans-retinyl acetate, $860 \mu \mathrm{g}$; cholecalciferol, $37.5 \mu \mathrm{g}$; D,L- $\alpha$-tocopherol acetate, $200 \mathrm{mg}$; menadione, $10 \mathrm{mg}$; thiamin, $15 \mathrm{mg}$; riboflavin, $25 \mathrm{mg}$; nicotinic acid, $75 \mathrm{mg}$; pantothenic acid, $30 \mathrm{mg}$; pyridoxine, $15 \mathrm{mg}$; folic acid, $5 \mathrm{mg}$; cyanocobalamin, $20 \mu \mathrm{g}$; ascorbyl monophosphate, $125 \mathrm{mg}$; biotin, $0.25 \mathrm{mg}$; Ca, $1.1 \mathrm{~g} ; \mathrm{ZnSO}$, $296 \mathrm{mg} ; \mathrm{MnSO}_{4}, 41 \mathrm{mg} ; \mathrm{CuSO}_{4}, 13 \mathrm{mg} ; \mathrm{CoSO}_{4}, 2.6 \mathrm{mg} ; \mathrm{Cal}_{2}, 3.5 \mathrm{mg}$; astaxanthin, $175 \mathrm{mg} ; \mathrm{Y}_{2} \mathrm{O}_{3}, 100 \mathrm{mg}$. 
inductively coupled plasma (PerkinElmer Optima 5300 DV; Perkin Elmer).

\section{Histology, immunohistochemistry and morphometry}

Routine histological examination was performed on formalinfixed and paraffin-embedded sections stained by haematoxylin and eosin. Scoring of the sections was performed according to the following criteria:

(1) Lamina propria - accumulation of leucocytes such as lymphocytes, granulocytes and eosinophilic granular cells in the lamina propria.

(2) Changes in the epithelium - reduced supranuclear vacuolisation, reduced cellular height and increased cytoplasmic basophilia.

(3) Atrophy - reduced height of the intestinal folds.

(4) Oedema - inflammatory oedema comprising accumulation of protein-rich fluid in the lamina propria.

The sections were given an individual score for each of the criteria above ranging from 0 to 2 , where 0 indicated no signs of abnormal changes, 1 weak changes, and 2 marked changes. The score 0.5 was given if slight changes appeared, although
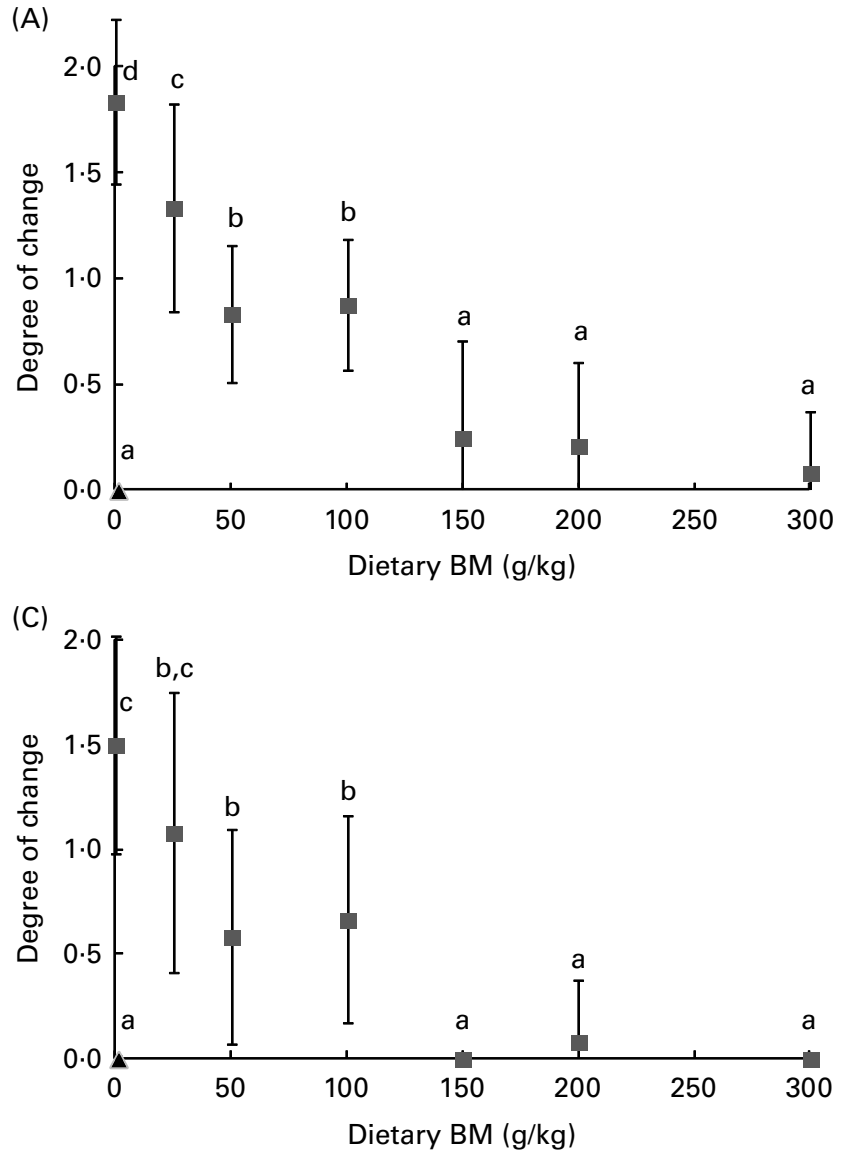

such changes were likely to be within the normal range. A score of at least 1 should be obtained for parameters $1-3$ in order to claim typical SBM-induced enteritis.

Paraffin sections from the distal intestine were used for immunohistochemistry. The procedures of antigen retrieval and immunostaining including details of antibodies used have been reported previously; for proliferating cell nuclear antigen (PCNA), the procedure was as described by Romarheim et $a l^{(6)}$, and for $\mathrm{CD} 8 \alpha$ and MHC II, the procedure followed was according to Hetland et al. ${ }^{(13)}$

$\mathrm{CD} 8 \alpha^{+}$cells and stretches of epithelial cells stained for PCNA were measured using ImageJ software (1.42q version; ImageJ). The quantities of $\mathrm{CD} 8 \alpha^{+}$cells were expressed as the density of stained cells at the base of the intestinal epithelium in simple folds. The length of stretches with PCNA-reactive epithelial cells was expressed in percentage of a baseline drawn through the base of the folds.

\section{Calculations and statistical analysis}

Feed intake during the experiment was expressed as DM in feed $\left(\mathrm{DM}_{\text {feed }}\right) /$ initial body weight $\left(\mathrm{BW}_{0}\right)$. Weight gain was calculated as:
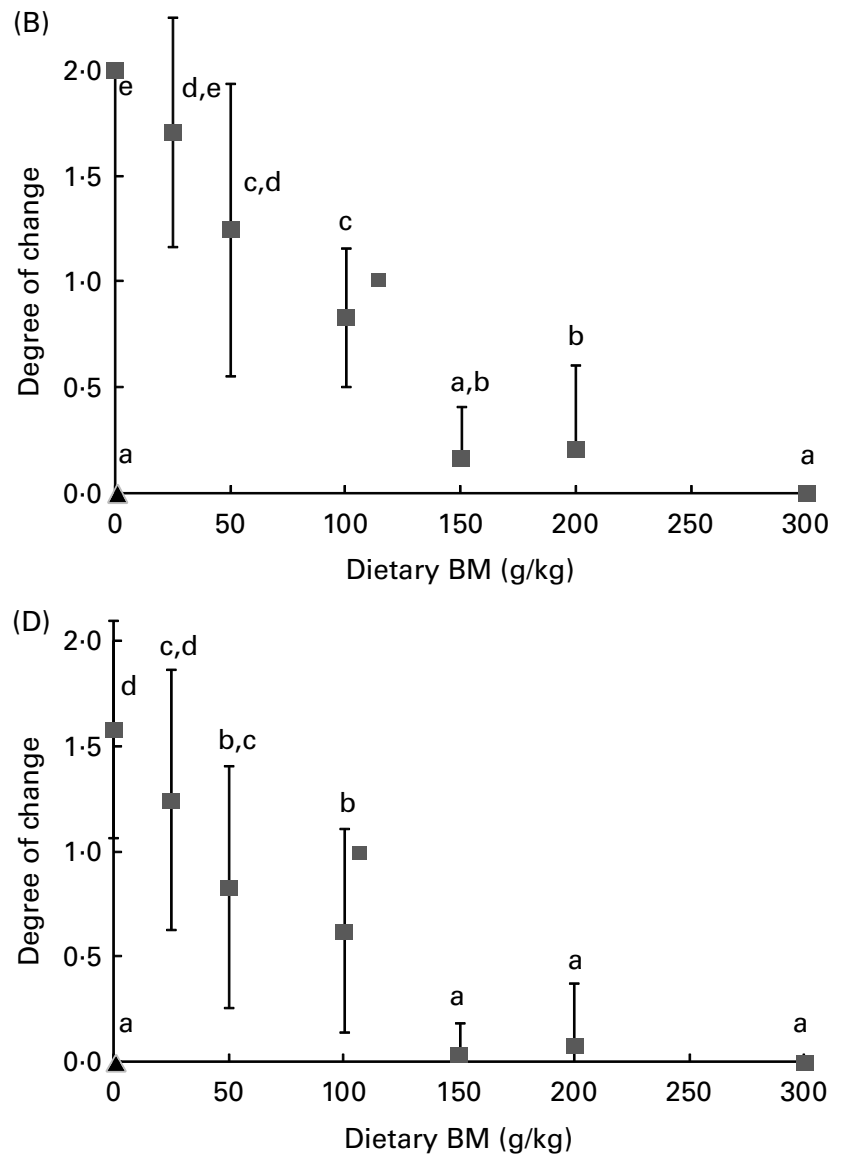

Fig. 1. Histological changes in the distal intestine of Atlantic salmon fed diets with $200 \mathrm{~g} / \mathrm{kg}$ soyabean meal in combination with increasing inclusion of bacterial meal $(B M, \square)$. The individual histological sections were evaluated with respect to changes in $(A)$ leucocyte infiltrates in the lamina propria/submucosa, (B) epithelium, (C) atrophy of the simple and complex folds and (D) oedema, i.e. accumulation of fluid in the lamina propria, and were given a grading of 0 (no signs of intestinal changes), 0.5 (traces of changes), 1 (weak changes) or 2 (marked changes). All sampled fish fed the FM diet ( $\Delta$ ) had a normal distal intestine as evaluated by the studied criteria. Values are means $(n 12)$, with standard deviations represented by vertical bars. ${ }^{a, b, c, d, e}$ Mean values with unlike letters were significantly different $(P<0.05)$. 

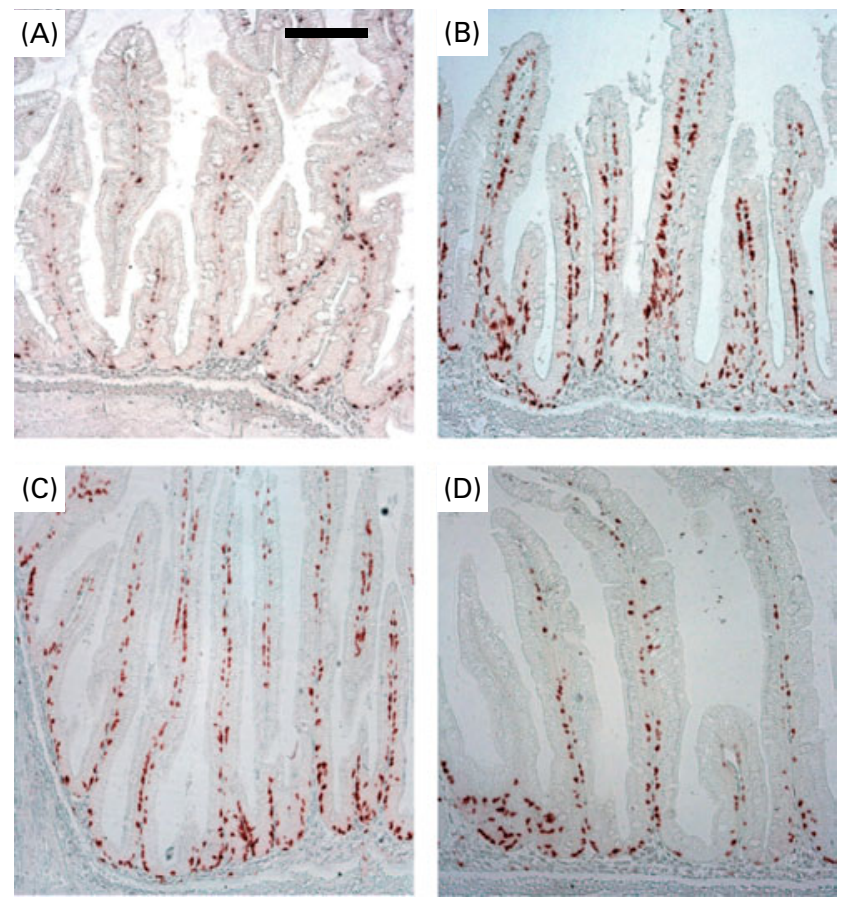

Fig. 2. Immunohistochemistry for CD8 $\alpha$. (A) Fish meal (FM) diet, (B) soyabean meal bacterial meal (BM) diet at $0 \mathrm{~g} / \mathrm{kg}(0-\mathrm{BM})$, (C) soyabean meal 50-BM diet and (D) soyabean meal 300-BM diet. Positive lymphocytes were largely confined to the basal part of the epithelium, although a few were found in the lamina propria/submucosa. On the 0-BM and 50-BM diets, a marked increase in the intensity of reaction was seen, whereas numbers were similar to those of the FM diet. Magnification is the same in (A)-(D); scale bar, $200 \mu \mathrm{m}$.

$$
\begin{aligned}
\text { Weight gain }= & 100 \times\left(\text { final body weight }\left(\mathrm{BW}_{1}\right)\right. \\
& \left.-\mathrm{BW}_{0}\right) / \mathrm{BW}_{0} .
\end{aligned}
$$

The feed conversion was calculated as:

$$
\text { Feed conversion }=\mathrm{DM}_{\mathrm{feed}} /\left(\mathrm{BW}_{1}-\mathrm{BW}_{0}\right) .
$$

Thermal growth coefficient (TGC) was calculated as:

$\mathrm{TGC}=1000 \times\left(\mathrm{BW}_{1}^{1 / 3}-\mathrm{BW}_{0}^{1 / 3}\right) /($ mean daily temperature $\times$ days in the experiment).

Apparent digestibility of nutrients was calculated as:

$$
\text { Apparent digestibility }=100 \times\left(1-\left(I_{\mathrm{D}} / I_{\mathrm{F}} \times N_{\mathrm{F}} / N_{\mathrm{D}}\right)\right) \text {, }
$$

where $I_{\mathrm{D}}$ and $I_{\mathrm{F}}$ represent the concentration of the inert marker in diets and faeces, and $N_{\mathrm{F}}$ and $N_{\mathrm{D}}$ represent the concentration of nutrients in faeces and diets, respectively.

The data were analysed by one-way ANOVA to determine the effects of diets, or Welch's test if the variances differed significantly among the treatments. Comparisons among treatment means were ranked by the least significant difference multiple-range test given a significant model. Quadratic regression analysis was applied to determine the effects of graded inclusion of BM in diets with the SBM. Non-parametric data from the histological evaluation were analysed by
Kruskal-Wallis ANOVA by ranks. Statistical analysis was performed using SAS procedures (SAS Institute, Inc.). $P<0.05$ was considered as statistically significant.

\section{Results}

\section{Histological and immunohistochemical evaluation}

All sampled fish fed the 0-BM diet developed typical SBM-induced enteritis with accumulation of leucocytes in the lamina propria, reduced supranuclear vacuolisation and cellular height of epithelial cells, increased epithelial cytoplasmic basophilia, atrophy with shortening of the simple and complex intestinal folds, and widening of the lamina propria and submucosa due to cellular infiltration and oedema (Figs. S1 and S2, available online), as previously described in details by Baeverfjord \& Krogdahl ${ }^{(1)}$. The morphological changes of the intestinal tissue gradually disappeared as the inclusion of the BM increased, and all features mentioned above were evaluated to concur with minor changes (scores between 0.5 and 1.0 ) when $50-100 \mathrm{~g} / \mathrm{kg}$ BM were added to the diets (Fig. 1). Fish fed diets with $150 \mathrm{~g} / \mathrm{kg} \mathrm{BM}$ and more had no or only weak signs of intestinal change, not significantly different from fish fed the FM diet. Occasionally (two of twelve fish on the 200-BM diet and one of twelve fish on the 300-BM diet), single and isolated leucocyte aggregates of mainly lymphocytes were found in an otherwise normal intestine. These aggregates were located in the lamina propria/submucosa above the stratum compactum. Large pale mononuclear cells were found in the centre of the aggregates in the individual fed the 300-BM diet, indicative of granuloma formation (results not shown).

Staining for $\mathrm{CD} 8 \alpha$ identified a population of $\mathrm{CD} 8 \alpha^{+}$ lymphocytes at the base of the intestinal epithelium (Fig. 2), in location corresponding to that earlier reported for CD3

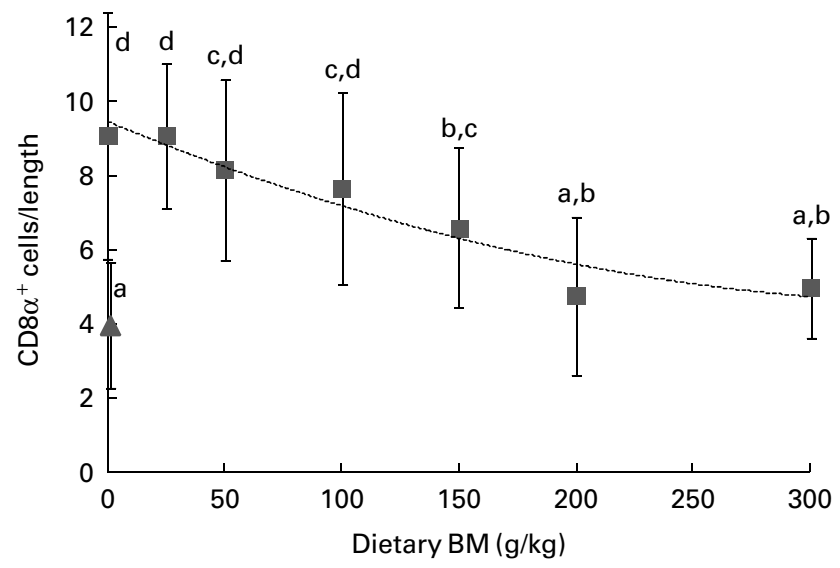

Fig. 3. Density of CD8 $\alpha^{+}$lymphocytes in the lamina propria and submucosa of the simple folds in the distal intestine of Atlantic salmon fed diets with different dietary combinations of soyabean meal (SBM) and bacterial meal (BM), or neither for $47 \mathrm{~d}$. The quantities of $\mathrm{CD} 8 \alpha^{+}$cells were expressed as the density of stained cells. Values are means ( $n$ 12), with standard deviations represented by vertical bars. ${ }^{a, b, c, d}$ Mean values with unlike letters were significantly different $(P<0.05)$. Quadratic equation: $y=9.45-0.026 x+0.000035 x^{2}, R^{2} 0.33, P<0.001$. $\square$, Fish meal diet; $\Delta$, diets with SBM. 

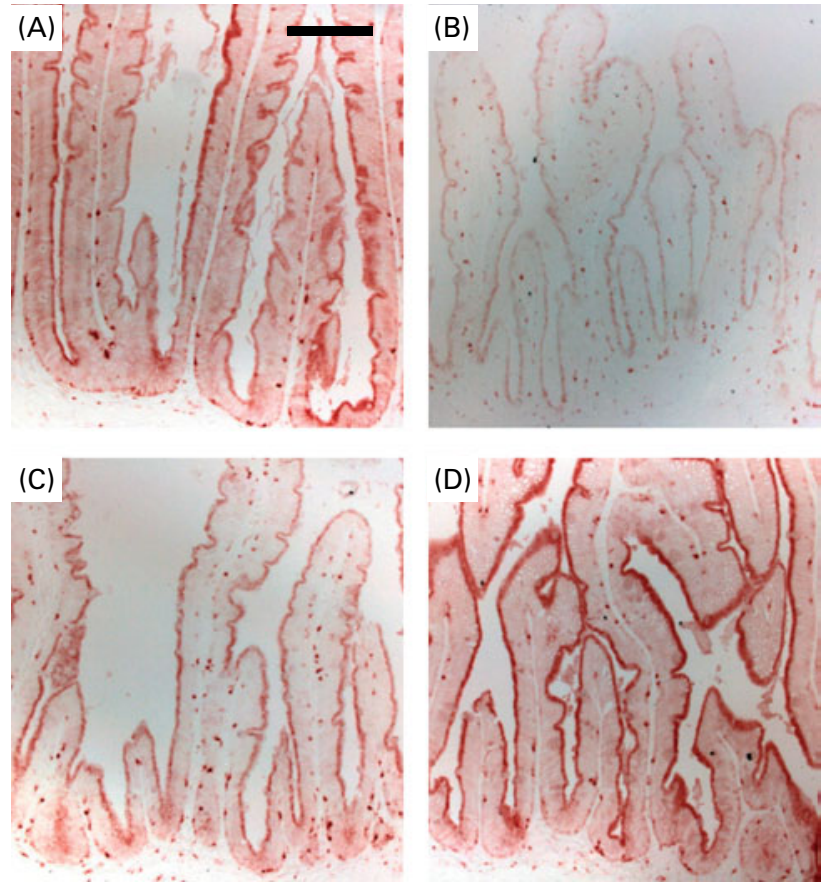

Fig. 4. Immunohistochemistry for MHC II. (A) Fish meal (FM) diet, (B) soyabean meal bacterial meal (BM) diet at $0 \mathrm{~g} / \mathrm{kg}(0-B M),(C)$ soyabean meal 50-BM diet and (D) soyabean meal 300-BM diet. On the FM diet and the $300-\mathrm{BM}$ diet, the staining pattern was quite similar: There was a strong reaction in the epithelium and particularly close to the luminal border. Reactive dendritic cells were seen in the basal part of the epithelium and scarcely in the lamina propria/submucosa. On the 0-BM and 50-BM diets, a marked decrease in the intensity of epithelial reaction was apparent. Scattered reactive dendritic cells were seen in the epithelium and lamina propria/ submucosa. Magnification is the same in (A)-(D); scale bar, $200 \mu \mathrm{m}$.

in salmon ${ }^{(12)} \cdot \mathrm{CD} \alpha^{+}$lymphocytes in the epithelium were more prevalent on the $0-\mathrm{BM}$ diet than on the FM diet. An increasing inclusion of $\mathrm{BM}$ resulted in a gradual decline in the density of $\mathrm{CD} 8 \alpha^{+}$intraepithelial lymphocytes, and inclusion of $200 \mathrm{~g} / \mathrm{kg}$ BM gave values not significantly different from that of fish fed the FM diet (Fig. 3). The lamina propria and submucosa also contained a considerable proportion of $\mathrm{CD} 8 \alpha^{+}$lymphocytes at low dietary BM levels (Fig. 2).

Staining for MHC II gave a strong reaction in the brush border and the supranuclear cytoplasm of the epithelium, in leucocytes at the base of the epithelium, and in scattered cells of the lamina propria and submucosa of fish fed the FM diet (Fig. 4). The reactive leucocytes often showed distinct reactive cytoplasmic extensions or dendrites, corresponding to a reaction in dendritic cells or macrophages. Such reactive leucocytes were numerous in fish fed the 0-BM diet, whereas the epithelial reaction was mostly conspicuously absent or weak. With increasing inclusion of $\mathrm{BM}$, this reaction approached that of fish fed the FM diet.

The epithelium of fish fed the 0-BM diet had the longest stretches of PCNA-stained cells, and the reactivity was reduced with increasing inclusion of BM (Fig. 5). Fish fed the diets with $150 \mathrm{~g} / \mathrm{kg} \mathrm{BM}$ or more had PCNA-stained stretches not significantly different from those fed the FM diet.

\section{Growth and nutrient digestibility}

Only one fish died $2 \mathrm{~d}$ after the experiment started; otherwise no mortality was observed. The ANOVA and regression analyses did not show any effects of diets on feed intake, weight gain, feed conversion ratio or TGC ( $P>0.05$; Table 2$)$. An effect of diet was found for crude protein digestibility $(P=0.037)$, i.e. slightly lower protein digestibility in fish fed the $300-\mathrm{BM}$ diet $(82 \cdot 2 \%)$ than in those fed the FM diet $(83.7 \%)$ and diets with $0-150 \mathrm{~g} / \mathrm{kg} \mathrm{BM}(83.8-84.9 \%)$. This effect was confirmed by a regression line $\left(R^{2} 0.60\right.$, $P=0.006$ ), indicating reduced protein digestibility with a high dietary inclusion of $\mathrm{BM}$, whereas moderate inclusion levels had a minor effect. Lipid digestibility ranged from 95 to $96 \%$, and starch digestibility from 63 to $69 \%$, but no significant effects of the diets were found.

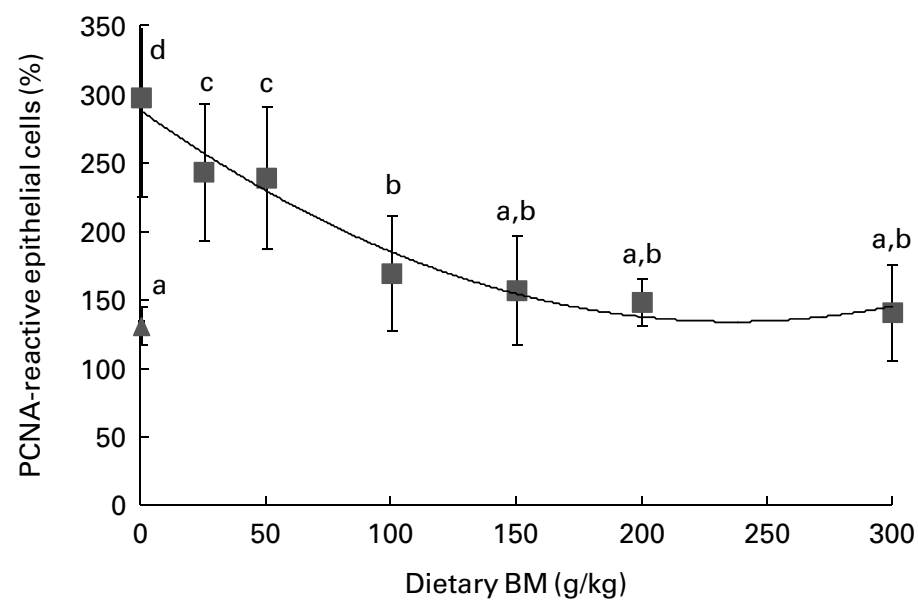

Fig. 5. Stretches of proliferating cell nuclear antigen (PCNA)-reactive epithelial cells in the distal intestine of Atlantic salmon fed diets with different dietary combinations of soyabean meal (SBM) and bacterial meal (BM), or neither for $47 \mathrm{~d}$. The length of PCNA stretches was measured and expressed in relation to a baseline drawn through the base of the folds. Values are means $(n 12)$, with standard deviations represented by vertical bars. ${ }^{\text {a,b,c,d }}$ Mean values with unlike letters were significantly different $(P<0.05)$. Quadratic equation: $y=289-1.32 x+0.0028 x^{2}, R^{2} 0.59, P<0.001$. $\square$, Fish meal diet; $\Delta$, diets with SBM. 
Table 2. Feed intake, growth, feed conversion and apparent digestibility of macronutrients in fish fed a fish meal (FM) diet or diets with $200 \mathrm{~g} / \mathrm{kg}$ soyabean meal in combination with increasing inclusion of bacterial meal (BM) for $47 \mathrm{~d}$

(Least square mean values with their pooled standard errors, $n 3$ tanks/diet)

\begin{tabular}{|c|c|c|c|c|c|c|c|c|c|c|}
\hline & FM diet & $\begin{array}{l}\text { 0-BM } \\
\text { diet }\end{array}$ & $\begin{array}{l}\text { 25-BM } \\
\text { diet }\end{array}$ & $\begin{array}{l}\text { 50-BM } \\
\text { diet }\end{array}$ & $\begin{array}{c}\text { 100-BM } \\
\text { diet }\end{array}$ & $\begin{array}{c}\text { 150-BM } \\
\text { diet }\end{array}$ & $\begin{array}{c}\text { 200-BM } \\
\text { diet }\end{array}$ & $\begin{array}{c}\text { 300-BM } \\
\text { diet }\end{array}$ & SEM & $P$ \\
\hline Feed intake ( $\mathrm{g} / \mathrm{kg}$ fish) & 717 & 665 & 682 & 778 & 656 & 663 & 645 & 639 & 55 & 0.67 \\
\hline Weight gain (\%) & 96 & 89 & 89 & 94 & 85 & 88 & 89 & 88 & $5 \cdot 1$ & 0.81 \\
\hline Feed:gain ratio & 0.75 & 0.75 & 0.77 & 0.82 & 0.77 & 0.76 & 0.73 & 0.73 & 0.023 & 0.26 \\
\hline TGC & 3.33 & $3 \cdot 18$ & $3 \cdot 16$ & $3 \cdot 27$ & 3.03 & 3.09 & 3.13 & $3 \cdot 10$ & $0 \cdot 12$ & 0.70 \\
\hline \multicolumn{11}{|l|}{ Apparent digestibility (\%) } \\
\hline Crude protein ${ }^{*}$ & $83 \cdot 7^{\mathrm{b}}$ & $84.9^{b}$ & $84 \cdot 1^{\mathrm{b}}$ & $84 \cdot 5^{\mathrm{b}}$ & $83.8^{\mathrm{b}}$ & $84 \cdot 8^{\mathrm{b}}$ & $83 \cdot 6^{a, b}$ & $82 \cdot 2^{\mathrm{a}}$ & 0.43 & 0.037 \\
\hline Crude lipid & 94.9 & $95 \cdot 6$ & 95.4 & $95 \cdot 7$ & $95 \cdot 0$ & $95 \cdot 6$ & $95 \cdot 3$ & $95 \cdot 6$ & 0.43 & 0.84 \\
\hline Starch & $63 \cdot 6$ & $64 \cdot 7$ & 63.3 & $64 \cdot 2$ & $64 \cdot 1$ & $69 \cdot 2$ & $66 \cdot 0$ & $63 \cdot 0$ & 1.49 & 0.21 \\
\hline
\end{tabular}

TGC, thermal growth coefficient.

a,b Mean values with unlike superscript letters were significantly different $(P<0.05)$.

${ }^{*}$ Quadratic equation: $y=-0.00003 x^{2}+0.002 x+84.5, R^{2} 0.60, P=0.006$. The FM diet was not included in the regression analysis.

\section{Liver and gut weights}

The weight of the distal intestine relative to the whole body weight was affected by the diet $(P=0.033)$, whereas no significant differences were found for total gut, liver, stomach, pyloric region or mid-intestine (Table 3 ). Fish fed the $25-\mathrm{BM}$ diet had the lowest distal intestine weight $(5 \cdot 2 \mathrm{~g} / \mathrm{kg}$ body weight) and fish fed the 300-BM diet had the highest weight $(7.0 \mathrm{~g} / \mathrm{kg}$ body weight). The regression analysis indicated that increasing dietary BM levels increased distal intestinal weights throughout the whole inclusion range.

\section{Discussion}

Healthy individuals maintain a fine balance between tolerance to the commensal intestinal microbiota and feed antigens on the one hand, and an appropriate immune response against both bona fide pathogens and potential pathogens, on the other hand. This homeostasis seems to be interrupted in salmonids fed SBM, but may be restored by sufficient dietary addition of BM produced on natural gas, as shown in the present experiment. The mobilisation of $\mathrm{CD} \alpha^{+} \mathrm{T}$ cells in the distal intestine of salmon with SBM-induced enteritis supports the interpretation that this is a T-cell-mediated inflammation $^{(11,12)}$. It seems likely from our immunohistochemical studies that a large percentage of the intraepithelial lymphocyte population is $\mathrm{CD} \alpha^{+}$, as observed in mammals ${ }^{(21)}$. It is thus possible that $\mathrm{CD} 8 \alpha^{+}$lymphocytes perform the same surveyor role in the salmon epithelium as in mammals, and that stress induced by SBM challenges $\mathrm{CD} 8 \alpha^{+}$lymphocytes to eliminate affected epithelial cells whether this is appropriate or not. Thus, SBM-induced enteropathy may resemble chronic intestinal conditions such as inflammatory bowel disease in humans, where the gut microbiota ${ }^{(22)}$ and the activation of Toll-like receptors at the basolateral surface of epithelial cells ${ }^{(23)}$ seem to play a central role. Dietary pro- and prebiotics may affect fish health through alteration of the intestinal microbiota $^{(14,24)}$, and the substitution of dietary FM by SBM has shown to alter the microbiota of salmonids ${ }^{(2-27)}$. Although Bakke-McKellep et al. ${ }^{(27)}$ reduced the population of bacteria adherent to the intestinal wall and in the digesta by adding $3 \mathrm{~g} / \mathrm{kg}$ of the broad-spectrum antibiotic oxytetracycline to a diet with SBM, no effect was observed on the severity of SBM-induced enteropathy.

The present experiment confirms that MHC II molecules are normal constituents of the salmon distal intestinal epithelium, as reported previously by Bakke-McKellep et al. ${ }^{(28)}$. An earlier study of rainbow trout lymphocytes derived from the intestinal epithelium showed that they have a polyclonal, differentiated profile and are probably quite responsive ${ }^{(29)}$, compatible with an active role of the epithelium in uptake, processing and presentation of luminal antigens. In the human ileum, MHC II reactivity has been demonstrated in multivesicular late

Table 3. Relative weights of the liver and gut in fish fed a fish meal (FM) diet or diets with $200 \mathrm{~g} / \mathrm{kg}$ soyabean meal in combination with increasing inclusion of bacterial meal (BM) for $47 \mathrm{~d}$

(Least square mean values with their pooled standard errors, $n 3$ tanks/diet)

\begin{tabular}{|c|c|c|c|c|c|c|c|c|c|c|}
\hline & $\begin{array}{l}\text { FM } \\
\text { diet }\end{array}$ & $\begin{array}{c}\text { 0-BM } \\
\text { diet }\end{array}$ & $\begin{array}{c}\text { 25-BM } \\
\text { diet }\end{array}$ & $\begin{array}{c}\text { 50-BM } \\
\text { diet }\end{array}$ & $\begin{array}{c}\text { 100-BM } \\
\text { diet }\end{array}$ & $\begin{array}{c}\text { 150-BM } \\
\text { diet }\end{array}$ & $\begin{array}{c}\text { 200-BM } \\
\text { diet }\end{array}$ & $\begin{array}{c}\text { 300-BM } \\
\text { diet }\end{array}$ & SEM & $P$ \\
\hline \multicolumn{11}{|c|}{ Organ weight (g/kg body weight) } \\
\hline Total gut & $79 \cdot 6$ & $81 \cdot 6$ & $78 \cdot 7$ & $79 \cdot 9$ & $79 \cdot 8$ & $76 \cdot 3$ & $80 \cdot 7$ & $81 \cdot 3$ & 1.93 & 0.64 \\
\hline Liver & $15 \cdot 7$ & $15 \cdot 4$ & 14.5 & $15 \cdot 2$ & $15 \cdot 8$ & 14.9 & $15 \cdot 4$ & $16 \cdot 3$ & 0.39 & 0.17 \\
\hline Stomach & 6.9 & $7 \cdot 3$ & $7 \cdot 0$ & $6 \cdot 7$ & $6 \cdot 6$ & $6 \cdot 7$ & $7 \cdot 0$ & $7 \cdot 2$ & 0.39 & 0.85 \\
\hline Pyloric region & $46 \cdot 6$ & 48.5 & $46 \cdot 7$ & $47 \cdot 3$ & 45.9 & 43.5 & $45 \cdot 5$ & $45 \cdot 8$ & 1.65 & 0.63 \\
\hline Mid-intestine & 2.9 & 2.9 & 3.0 & 3.0 & 3.3 & 3.3 & 3.3 & $3 \cdot 1$ & 0.23 & 0.68 \\
\hline Distal intestine* & $5 \cdot 8^{a, b}$ & $5 \cdot 6^{a, b}$ & $5 \cdot 2^{a}$ & $5 \cdot 6^{a, b}$ & $6 \cdot 3^{\mathrm{b}, \mathrm{c}}$ & $6 \cdot 1^{a, b, c}$ & $6 \cdot 8^{\mathrm{c}}$ & $7 \cdot 0^{\mathrm{c}}$ & 0.30 & 0.03 \\
\hline
\end{tabular}

a,b,c Mean values with unlike superscript letters were significantly different $(P<0.05)$.

*Quadratic equation: $y=-0.000008 x^{2}+0.008 x+5 \cdot 3, R^{2} 0.68, P=0.002$. The FM diet was not included in the regression analysis. 
endosomes $^{(30)}$, and the findings in mice suggest that ileal epithelial MHC II reactivity might signify an antigen presentation by MHC II carried by exosomes ${ }^{(31)}$. Secretion of MHC II $\beta$-containing exosomes has also been found in head kidney leucocytes from salmon ${ }^{(32)}$. Multivesicular endosomes are also present in the distal intestinal epithelium of rainbow trout $^{(33)}$, although it is not known whether these multivesicular bodies are involved in the production of exosomes. Many teleosts, including salmonids, are also equipped for the uptake of intact or partially fragmented proteins through the distal intestine ${ }^{(34)}$, and this function is impaired in fish with SBM-induced enteritis ${ }^{(5)}$. The MHC II reaction in epithelial cells in the distal part of the salmon intestine might therefore be associated with endocytic and/or exocytic activity.

The role of MHC II in the epithelium is not fully elucidated, but its constituent character suggests that it is not necessarily involved in the pro-inflammatory scenario that signifies fully developed SBM-induced enteritis. A role in exosome production or T-cell development/reactivity could be more likely, catering to the intraepithelial lymphocytes or dendritic cells as part of a role in maintaining intestinal homeostasis or tolerance. In such a perspective, the decline of MHC II during SBM-induced enteritis could also imply the lack of maturity associated with increased turnover of epithelial cells. The lack of epithelial differentiation and maturity in fish with SBM-induced enteritis is also supported by the enlarged stretches of PCNA-stained cells, and the lack of carbonic anhydrase isoenzyme 12 in the brush border found in a previous study ${ }^{(6)}$. The role of MHC II on dendritic cells or macrophages is more obvious. Although present in the normal intestinal mucosa, MHC II-bearing dendritic cells clearly represent a constituent of the inflammatory infiltrate, such as the increased presence of $\mathrm{CD} 8 \alpha^{+} \mathrm{T}$ cells. The lack of suitable antibodies in fish prevented a further dissection of pathogenesis by immunohistochemistry. However, the mRNA expression of $\mathrm{CD} 4, \mathrm{CD} 8 \alpha$ and $\mathrm{CD} 8 \beta$ was up-regulated about two-fold in the distal intestine of Atlantic salmon with SBMinduced enteritis ${ }^{(12)}$, which suggests active $\mathrm{CD}^{+}$populations.

What could be the mechanism for the ameliorating effect of $\mathrm{BM}$ on SBM-induced enteritis? Most probably the effect is related to mechanisms ensuring tolerance to feed antigens and the commensal intestinal microbiota. Regulatory $\mathrm{CD}^{+}$ and $\mathrm{CD}^{+} \mathrm{T}$ cells $\left(\mathrm{T}_{\text {reg }}\right)$ expressing the forkhead box $\mathrm{p} 3$ (Foxp3) transcription factor are important for keeping an inflammatory action against food antigens and commensal bacteria at bay in humans and mice, and a reduction of $\mathrm{T}_{\text {reg }}$ cells may interrupt the fine-tuned homeostasis and lead to inflammatory bowel disease $\mathrm{e}^{(35,36)}$. Rainbow trout express both a Foxp $3 a$ and Foxp $3 b$ gene with high similarities to mammals in the C-terminal region but with less homology in the $\mathrm{N}$ terminal region ${ }^{(37)}$. A CD 4- $2^{+}$CD25-like ${ }^{+}$Foxp3-like ${ }^{+}$phenotype has been found in pufferfish, resembling $\mathrm{CD} 4^{+} \mathrm{CD} 25^{+-}$ Foxp $3^{+} \mathrm{T}_{\text {reg }}$ cells in mammals, and depletion of these cells lead to intestinal inflammation, indicating a similar $\mathrm{T}_{\text {reg }}$ immunological system in fish and mammals ${ }^{(38)}$. A stimulatory effect on $\mathrm{T}_{\text {reg }}$ would thus be one of the most attractive candidate pathways for the homeostasis-supporting effect of BM. It is also possible that the pathway includes a microbial pattern recognition receptor in the brush border ${ }^{(23)}$. Such receptors might detect the known massive presence of microbial products on a $\mathrm{BM}$ diet. Receptors residing in the luminal brush border have been shown to be involved in subduing inflammation. Thus, deleterious host pro-inflammatory responses can be modulated or prevented by microbiotaderived factors ${ }^{(22)}$. BM might thus have a protective effect on the epithelial cells resembling that of intestinal microbial commensals.

Feed intake, growth and nutrient utilisation are dependent on the characteristics of fish, experimental conditions and diets, and an evaluation of these parameters is important to unveil possible artifacts in the experiment. Feed intake in the present experiment was similar or slightly lower than recent table values for commercial farming of Atlantic salmon provided by Skretting AS ${ }^{(39)}$, whereas the feed conversion ratio was similar or slightly better. The slightly reduced crude protein digestibility with increasing $\mathrm{BM}$ inclusion is similar to previous results for salmonids ${ }^{(6,17,40)}$. This effect is likely to be caused by cell-wall components in BM, as seen with yeast products fed to salmonids ${ }^{(41)}$, and by the extensive intracytoplasmic membranes in $M$. capsulatus grown on natural gas, as suggested by Skrede et $a l .^{(42)}$.

The weights of the distal intestine were almost identical to those found by Romarheim et al. ${ }^{(6)}$ when feeding similar diets. Fish with SBM-induced enteritis suffer from an excessive loss of epithelial cells in the distal intestine that lowers the weight of this segment ${ }^{(43,44)}$, and the increased proliferation indicated by the long stretches of PCNA-stained cells cannot compensate for this loss. The finding that the relative weight of the distal intestine continued to increase with $\mathrm{BM}$ inclusion above the level necessary to prevent enteritis suggests that BM stimulates intestinal growth. This might be due to the high content of purine and pyrimidine bases in BM that can serve as growth substrates for intestinal epithelial cells ${ }^{(16)}$

Soya is a suitable protein source for farmed fish with its relatively constant and well-balanced amino acid composition, but the morphological changes found with inclusion levels of a SBM as low as $7 \cdot 6 \%^{(2)}$ have been a major constrain for its use in diets for salmonids. The present findings open up for higher dietary inclusions of a SBM, if combined with BM.

It is concluded that the protective effect of BM against SBMinduced enteritis in salmon is dose dependent. The inflammatory response is linked to the enhanced density of $\mathrm{CD} 8 \alpha^{+} \mathrm{T}$ lymphocytes at the base of the epithelial cells and MHC IIreactive cells in the lamina propria and submucosa. The level of MHC II was, however, reduced in the epithelial cells and brush border in fish with an inflamed intestine. The level of these inflammatory regulators was normalised by adequate dietary inclusion of $\mathrm{BM}$, but the underlying regulatory mechanisms remain unknown.

\section{Supplementary material}

To view supplementary material for this article, please visit http://dx.doi.org/10.1017/S0007114512002899 


\section{Acknowledgements}

This study was supported by the Research Council of Norway (grant no. 182543). O. H. R. had primary responsibility for the experimental design, feed production, fish experiment, statistically analyses and the writing of the manuscript. D. L. H. performed the immunohistochemistry, analysed the data and contributed to the writing of the manuscript. A. S., M. $\varnothing$. and L. T. M. were involved in the design of the experiment and manuscript drafting. T. L. was involved in the design of the experiment, performed the histology evaluation and contributed to the writing of the manuscript. All authors read and approved the final manuscript. The authors have no conflicts of interest to declare.

\section{References}

1. Baeverfjord G \& Krogdahl ^ (1996) Development and regression of soybean meal induced enteritis in Atlantic salmon, Salmo salar L., distal intestines: a comparison with the intestines of fasted fish. J Fish Dis 19, 375-387.

2. Krogdahl Å, Bakke-McKellep AM \& Baeverfjord G (2003) Effects of graded levels of standard soybean meal on intestinal structure, mucosal enzyme activities, and pancreatic response in Atlantic salmon (Salmo salar L.). Aquacult Nutr 9, 361-371.

3. Uran PA, Schrama JW, Jaafari S, et al. (2009) Variation in commercial sources of soybean meal influences the severity of enteritis in Atlantic salmon (Salmo salar L.). Aquacult Nutr 15, 492-499.

4. Nordrum S, Bakke-McKellep AM, Krogdahl A, et al. (2000) Effects of soybean meal and salinity on intestinal transport of nutrients in Atlantic salmon (Salmo salar L.) and rainbow trout (Oncorbynchus mykiss). Comp Biochem Physiol Part B 125, 317-335.

5. Uran PA, Aydin R, Schrama JW, et al. (2008) Soybean meal-induced uptake block in Atlantic salmon Salmo salar distal enterocytes. J Fish Biol 73, 2571-2579.

6. Romarheim OH, Øverland M, Mydland LT, et al. (2011) Bacteria grown on natural gas prevent soybean mealinduced enteritis in Atlantic salmon. J Nutr 141, 124-130.

7. Bakke-McKellep AM, Press CMcL, Baeverfjord G, et al. (2000) Changes in immune and enzyme histochemical phenotypes of cells in the intestinal mucosa of Atlantic salmon, Salmo salar L., with soybean meal-induced enteritis. J Fish Dis 23, 115-127.

8. Lilleeng E, Froystad MK, Ostby GC, et al. (2007) Effects of diets containing soybean meal on trypsin mRNA expression and activity in Atlantic salmon (Salmo salar L). Comp Biochem Physiol Part A 147, 25-36.

9. Knudsen D, Jutfelt F, Sundh H, et al. (2008) Dietary soya saponins increase gut permeability and play a key role in the onset of soyabean-induced enteritis in Atlantic salmon (Salmo salar L.). Br J Nutr 100, 120-129.

10. van den Ingh TSGAM, Olli JJ \& Krogdahl Å (1996) Alcoholsoluble components in soybeans cause morphological changes in the distal intestine of Atlantic salmon, Salmo salar L. J Fish Dis 19, 47-53.

11. Lilleeng E, Penn M, Haugland $\varnothing$, et al. (2009) Decreased expression of TGF- $\beta$, GILT and T-cell markers in the early stages of soybean enteropathy in Atlantic salmon (Salmo salar L.). Fish Shellfish Immunol 27, 65-72.
12. Bakke-McKellep AM, Frøystad MK, Lilleeng E, et al. (2007) Response to soy: T-cell-like reactivity in the intestine of Atlantic salmon, Salmo salar L. J Fish Dis 30, 13-25.

13. Hetland DL, Jørgensen SM, Skjødt K, et al. (2010) In situ localisation of major histocompatibility complex class I and class II and CD8 positive cells in infectious salmon anaemia virus (ISAV)-infected Atlantic salmon. Fish Shellfish Immunol 28, 30-39.

14. Merrifield DL, Dimitroglou A, Foey A, et al. (2010) The current status and future focus of probiotic and prebiotic applications for salmonids. Aquaculture 302, 1-18.

15. Ring $\varnothing$ E, Olsen RE, Gifstad TO, et al. (2010) Prebiotics in aquaculture: a review. Aquacult Nutr 16, 117-136.

16. Li P \& Gatlin DM (2006) Nucleotide nutrition in fish: current knowledge and future applications. Aquaculture 251, $141-152$.

17. Øverland M, Tauson A-H, Shearer K, et al. (2010) Evaluation of methane-utilising bacteria products as feed ingredients for monogastric animals. Arch Anim Nutr 64, 171-189.

18. Storebakken T, Baeverfjord G, Skrede A, et al. (2004) Bacterial protein grown on natural gas in diets for Atlantic salmon, Salmo salar, in freshwater. Aquaculture 241, 413-425.

19. Helland SJ, Grisdale-Helland B \& Nerland S (1996) A simple method for the measurement of daily feed intake of groups of fish in tanks. Aquaculture 139, 157-163.

20. Austreng E (1978) Digestibility determination in fish using chromic oxide marking and analysis of contents from different segments of the gastrointestinal tract. Aquaculture 13, $265-272$.

21. Cheroutre H, Lambolez F \& Mucida D (2011) The light and dark sides of intestinal intraepithelial lymphocytes. Nat Rev Immunol 11, 445-456.

22. Cerf-Bensussan N \& Gaboriau-Routhiau V (2010) The immune system and the gut microbiota: friends or foes? Nat Rev Immunol 10, 735-744.

23. Abreu MT (2010) Toll-like receptor signalling in the intestinal epithelium: how bacterial recognition shapes intestinal function. Nat Rev Immunol 10, 131-144.

24. Nayak SK (2010) Role of gastrointestinal microbiota in fish. Aquacult Res 41, 1553-1573.

25. Mansfield GS, Desai AR, Nilson SA, et al. (2010) Characterization of rainbow trout (Oncorbynchus mykiss) intestinal microbiota and inflammatory marker gene expression in a recirculating aquaculture system. Aquaculture 307, 95-104.

26. Merrifield DL, Dimitroglou A, Bradley G, et al. (2009) Soybean meal alters autochthonous microbial populations, microvilli morphology and compromises intestinal enterocyte integrity of rainbow trout, Oncorbynchus mykiss (Walbaum). J Fish Dis 32, 755-766.

27. Bakke-McKellep AM, Penn MH, Salas PM, et al. (2007) Effects of dietary soybean meal, inulin and oxytetracycline on intestinal microbiota and epithelial cell stress, apoptosis and proliferation in the teleost Atlantic salmon (Salmo salar L.). Br J Nutr 97, 699-713.

28. Bakke-McKellep AM, Koppang EO, Gunnes G, et al. (2007) Histological, digestive, metabolic, hormonal and some immune factor responses in Atlantic salmon, Salmo salar L., fed genetically modified soybeans. J Fish Dis 30, 65-79.

29. Bernard D, Six A, Rigottier-Gois L, et al. (2006) Phenotypic and functional similarity of gut intraepithelial and systemic T cells in a teleost fish. J Immunol 176, 3942-3949.

30. Hundorfean G, Zimmer KP, Strobel S, et al. (2007) Luminal antigens access late endosomes of intestinal epithelial cells enriched in MHC I and MHC II molecules: in vivo study in Crohn's ileitis. Am J Physiol Gastrointest Liver Physiol 293 G798-G808. 
31. Büning J, von Smolinski D, Tafazzoli K, et al. (2008) Multivesicular bodies in intestinal epithelial cells: responsible for MHC class II-restricted antigen processing and origin of exosomes. Immunology 125, 510-521.

32. Iliev DB, Jørgensen SM, Rode M, et al. (2010) CpGinduced secretion of MHCII $\beta$ and exosomes from salmon (Salmo salar) APCs. Dev Comp Immunol 34, 29-41.

33. Ezeasor DN \& Stokoe WM (1981) Light and electron-microscopic studies on the absorptive cells of the intestine, ceca and rectum of the adult rainbow-trout, Salmo-Gairdneri, Rich. J Fish Biol 18, 527-544.

34. Sire MF \& Vernier JM (1992) Intestinal absorption of protein in teleost fish. Comp Biochem Physiol Part A 103, 771-781.

35. Fleissner D, Frede A, Knott M, et al. (2011) Generation and function of immunosuppressive human and murine $\mathrm{CD} 8(+) \mathrm{T}$ cells by transforming growth factor-beta and retinoic acid. Immunology 134, 82-92.

36. Hardenberg G, Steiner TS \& Levings MK (2011) Environmental influences on $\mathrm{T}$ regulatory cells in inflammatory bowel disease. Semin Immunol 23, 130-138.

37. Wang TH, Monte MM, Huang WS, et al. (2010) Identification of two FoxP3 genes in rainbow trout (Oncorbynchus mykiss) with differential induction patterns. Mol Immunol 47, 2563-2574.

38. Wen Y, Fang W, Xiang LX, et al. (2011) Identification of Treg-like cells in Tetraodon: insight into the origin of regulatory $\mathrm{T}$ subsets during early vertebrate evolution. Cell Mol Life Sci 68, 2615-2626.
39. Skretting (2011) Den norske fôrkatalogen 2011 (The Norwegian feed catalogue 2011). http://www.skretting.no/ internet/SkrettingNorway/webInternet.nsf/wprId/EF7D72CEB5DAC35CC12573EE00284256!OpenDocument (accessed January 2012).

40. Aas TS, Grisdale-Helland B, Terjesen BF, et al. (2006) Improved growth and nutrient utilization in Atlantic salmon (Salmo salar) fed diets containing a bacterial protein meal. Aquaculture 259, 365-376.

41. Rumsey GL, Hughes SG, Smith RR, et al. (1991) Effect of high dietary concentrations of brewer's dried yeast on growth performance and liver uricase in rainbow trout (Oncorbynchus mykiss). Anim Feed Sci Technol 33, $177-183$.

42. Skrede A, Mydland LT \& Øverland M (2009) Effects of growth substrate and partial removal of nucleic acids in the production of bacterial protein meal on amino acid profile and digestibility in mink. J Anim Feed Sci 18, 689-698.

43. Refstie S, Bakke-McKellep AM, Penn M, et al. (2006) Capacity for digestive hydrolysis and amino acid absorption in Atlantic salmon (Salmo salar) fed diets with soybean meal or inulin with or without addition of antibiotics. Aquaculture 261, 392-406.

44. Romarheim OH, Skrede A, Gao Y, et al. (2006) Comparison of white flakes and toasted soybean meal partly replacing fish meal as protein source in extruded feed for rainbow trout (Oncorbynchus mykiss). Aquaculture 256, 354-364. 